\title{
PERCEPTION AND ADAPTATION OF THE PRODUCERS TO THE IMPACTS OF CLIMATE CHANGE IN APPLE PRODUCTION: AN ASSESSMENT OF MUSTANG DISTRICT OF NEPAL
}

\author{
Uttam Khanal ${ }^{1}$
}

\begin{abstract}
A study was conducted to assess the perception of farmers, researchers and related stakeholders on the impacts of climate change in apple production in Mustang district of Nepal. Focus group discussion (FGD) and key informants interviews were organized to explore the major climate hazards, relationship of climate hazards to apple production, impacts of climate change and potential adaptation measures. Increased temperature, drying up of water resources, increased northern wind, high speed wind, less snowfall and prolonged droughts were found as the major climatic hazards in the district. Use of alternative and/or additional sources of irrigation water; use of low chilling, drought tolerant and early maturing varieties; adoption of efficient irrigation methods and conservation agriculture practices were identified as the important adaptation measures.
\end{abstract}

KEY WORDS: Climate change, climate hazards, adaptation measures, apple INTRODUCTION

The climate is changing and weather patterns are becoming increasingly extreme and unpredictable (IPCC, 2007). The global temperatures are likely to increase by $1.1-6.4^{\circ} \mathrm{C}$ from 1990 to 2100 though the speed at which the temperature will rise is still debated (IPCC, 2002). The IPCC predicted that the atmospheric temperature of Hindu Kush Himalayan Region will undergo an increase of $5-6^{\circ} \mathrm{C}$. Mountainous regions in Nepal are experiencing increases in temperature (Shrestha et al., 1999) much greater than the global average (Eriksson et al. 2009). Although this increase will provide comparative advantage to some crops in few regions of the world, the overall impacts of climate change on agriculture are expected to be negative, alarming the global food security and malnutrition.

Nepal's economy is dominated by agriculture, which accounts for over one third of GDP and employs more than two thirds of the population (MoAC, 2010). Due to the wide range of climatic variability, Nepal has great opportunity to produce different types of fruits. Changing dietary habits of the people and the increasing awareness on balanced diet has increased the demand of fruits in the recent years (MoAC, 2010). Although the area and production of fruits has been increasing in the country (Table 1), per capita fruit consumption is far below the recommended level and only $45 \%$ of the local demand of fruits is met by domestic production. This can be further supported by a study conducted in 2002-2003 which showed that $98.1 \%$ of men and $99 \%$ of women in Nepal did not have adequate fruit and

\footnotetext{
${ }^{1}$ M.Sc. Ag. Local Initiatives for Biodiversity, Research and Development (LI-BIRD) Telephone: 00977-61535357 Email: utkhanal@gmail.com
} 
vegetable consumption, even though only $13.7 \%$ of the study population was urban (Hall et al, 2009).

Table 1. Area and production of fruits in Nepal

\begin{tabular}{|c|c|c|c|}
\hline Year & Total Area (ha) & Productive Area (ha) & Production (Mt) \\
\hline $2000 / 01$ & 73775 & 48166 & 487326 \\
\hline $2001 / 02$ & 77537 & 49780 & 473621 \\
\hline $2002 / 03$ & 80426 & 51016 & 518864 \\
\hline $2003 / 04$ & 86707 & 54111 & 511406 \\
\hline $2004 / 05$ & 89312 & 55348 & 552879 \\
\hline $2005 / 06$ & 91923 & 56549 & 535449 \\
\hline $2006 / 07$ & 94901 & 57595 & 575095 \\
\hline $2007 / 08$ & 100099 & 63432 & 630563 \\
\hline $2008 / 09$ & 103651 & 68785 & 686213 \\
\hline $2009 / 10$ & 107322 & 70722 & 706972 \\
\hline $2010 / 11$ & 117932 & 79184 & 794164 \\
\hline $2011 / 12$ & 139321 & 101233 & 1029754 \\
\hline
\end{tabular}

(Source: MoAD 2012)

Apple is one of the high value commodities that could be grown in high hills and mountains of Nepal (FNCCI, 2012). Government of Nepal has given high priority for developing apple production in identified pocket areas. High quality apples could be produced in sub-humid and dry temperate areas in Himalayan region of Nepal ranging from $1800 \mathrm{~m}-2800 \mathrm{~m}$ above mean sea level. Such rain shadow or low rainfall areas are mostly located in the Western and Mid Western mountainous regions of Nepal (Devkota, 1999). Mustang district is one of them in the Western Development Region. Mustang has already been identified and proved as one of the potential districts for commercial cultivation of apple. Marpha known as delightful apple capital of Nepal is located in Mustang district. The Government of Nepal has established the apple farm in Marpha, Mustang in 1966 realizing the suitability for producing the quality apples. The national as well as international market has recognized the apple produced in Mustang is the finest quality in terms of crispiness and juiciness. The processed apple into alcoholic product from the district has become very popular throughout the country. Other processed products of apple are juice, cider and air dried apple slices which are also becoming popular in the recent years.

Due to the recently opened fair weather road upto the district headquarter, many villages within the district are being accessible gradually. This road access has led the farmers to fetch the good price of their apple at their farm gates. Because of this good market price, more and more farmers are found interested in apple production. Productive area under apple has reached to 5674 ha in 2011 which was 3006 ha in 1997 (MoAD. 2012). 
Farmers of Mustang are facing the problems of more frequent and seriousness of diseases and insect pest's infestations in their apple orchards in the recent years. Due to this, the productivity of the apples is in decline. The villages of lower Mustang particularly Lete, Kunjo, Kobang, Tukuche and Marpha has experienced more infestations in the recent years comparing to the higher altitude areas. Offseason flowering has also been observed in high altitudes crops like peach, pear and apple (Malla, 2008).

Thus, a deeper understanding of the interdependence between changing climatic conditions and apple production together with adaptation options is crucial. Information about farmers' perception of climate change and adaptation approaches would assist policymakers to decrease the farmer's vulnerability to the adverse impacts of climate change.

\section{OBJECTIVE OF THE STUDY}

To assess the perception of farmers, extension workers and researchers on climate change and its impacts on apple production

To identify the climate hazards that negatively affects the apple production

To assess the potential adaptation strategies against the negative impacts of changing climate

\section{METHODOLOGY}

The study used a focus group discussion in Mustang district with farmers and relevant district level stakeholders held in 2012. The stakeholders were District Agricultural Development Office, Temperate Horticulture Development Centre (THDC), District Development Committee, Annapurna Conservation Area Project, and District Livestock Service Office amongst others. Key informants survey with progressive farmers and technical personnel from District Agricultural Development Office and Temperate Horticulture Development Centre was also conducted to assess in-depth ideas on the impact of climate change in Mustang district in relation to apple production.

\section{RESULTS AND DISCUSSIONS}

\section{IMPACTS OF CLIMATE CHANGE}

The study found that increased temperature, drying up of water sources, ncreased Northern wind, high speed wind, decreased snowfall and longer drought periods re the major climate hazards in the district particularly in the lower Mustang

(Figure1) These all factors are affecting negatively in the apple production both in 
terms of quantity and quality (Annex 1).

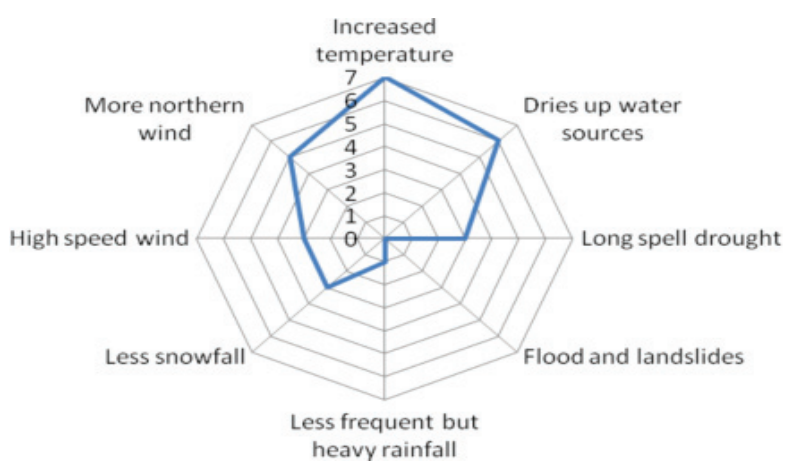

Figure 1. Perceived climate events in the study area (Source: FGD, 2012)

When asked about the impact of climate change in apple production, most of the apple growers responded that the production is reduced. According to them, the reduced snowfall and it's change in timing has attributed to this reduced production. It is revealed that the quantity and frequency of snowfall has been decreased significantly over the last decade.

A woman farmer in Marpha recalls: "Till late 1990s, we used to have huge snowfall and all the land used to be covered up with upto 2 to 3 feet of snow in the winter months. Once, I was supposed to visit back my parent's home in Dhumba immediate after my marriage, I had to cancel because of unexpected heavy snow fall. I remember that was one of the heaviest snowfalls I have ever seen; it went for 4 consecutive days. Before 15-20 years ago, we used to play with snow and enjoy a lot but nowadays that's a rare dream".

When talking about the decreasing snowfall, they compare amounts of snowfall at several places in past and present years to indicate a pattern. They professed frequency of early snow events in December and January had decreased over time with snowfall now often occurring in February, March and even April. The apple growers perceived the impact of change in snowfall timing is more crucial than reduction in amount of snowfall. They claimed early snowfall is more beneficial for agriculture. Jeevan Gurung of Pangling village claimed that early snow is more long lasting and melt slowly than late snow which results more infiltration of moisture in soil and increase the soil moisture. Late snow on the other hand, melts faster and there is more surface runoff. This also leads to high humidity in March, April and May which results more conducive environment for disease like apple scab and insect like wooly aphid infestation.

Some apple growing farmers perceive that increase in temperature is also equally affecting apple production in the district. They claimed that this increase in 
temperature favors infestation of pest, increased fruit drop, drying up of water resources resulting into shortage of irrigation water. This shortage ultimately results in to the decline in productivity of apple orchards.

The perception of extension worker and researcher is somewhat different than apple growing farmers. They claimed that poor orchard management is the reason behind the decline in productivity of apple in the district, in addition to the changing climate effects. Mr. Dharma Prasad Devkota, Senior Horticultural Developement Officer of THDC opines that the increased temperature and change in amount and timing of snowfall has negative impact in apple production. One of the causes of the present decrease in productivity is the lack of pollinizers. According to him, farmers have cut down the pollinizer varieties and planted commercial varieties. Those who are managing their orchards well still get good crops. He further questions, has climate not changed for them? According to the technicians, the farmers have sprayed excessive amount of pesticides in the recent years which also killed the beneficial insects. This also has adverse effect on soil and human health.

The increasing incidence of failure of the apple crop has led to the diversification of cropping pattern in many areas in the lower part of the district. Farmers are now growing medicinal plants, potatoes, beans and vegetables. But in upper areas, the acreage for apple cultivation is increasing in the recent years and more and more farmers have been involved in apple cultivation individually as well as in groups. The changing climate has negative impacts in lower part but positive impacts in the upper part of the district for apple cultivation.

\section{ADAPTATION STRATEGIES}

Focus group discussion with apple growing farmers, extension workers and researchers in the district identified eight different strategies to adapt to the impacts of climate change in apple cultivation considering urgency, sustainability and feasibility (Figure 2).

The serious impact of climate change is the lack of irrigation water. Hence, going for alternative source of irrigation was identified as the most urgent need in the district to adapt to the changing climate. FGD participants identified the alternatives for this are either to explore the natural spring sources of water or to pump the water from Kaligandaki River for irrigation. Other important adaptation strategies identified were use of low chilling, early maturing and drought tolerant varieties of apple, use of efficient irrigation methods (e.g. drip irrigation) and conservation agriculture practices.

Pema Dhundu Gurung, an apple growing farmer in Pangling village said confidently that to adapt to the lack of irrigation water we must lift the water from Kaligandaki River and collect in a pond above the village so that we could supply it to the field below. He added, even if they explore other springs nearby, this may dry up quickly in association with less snowfall and prolonged drought as observed in the recent years. Other adaptation measure against increased temperature 
could be the adoption of low chilling apple varieties that can give good production comparatively in higher temperature.

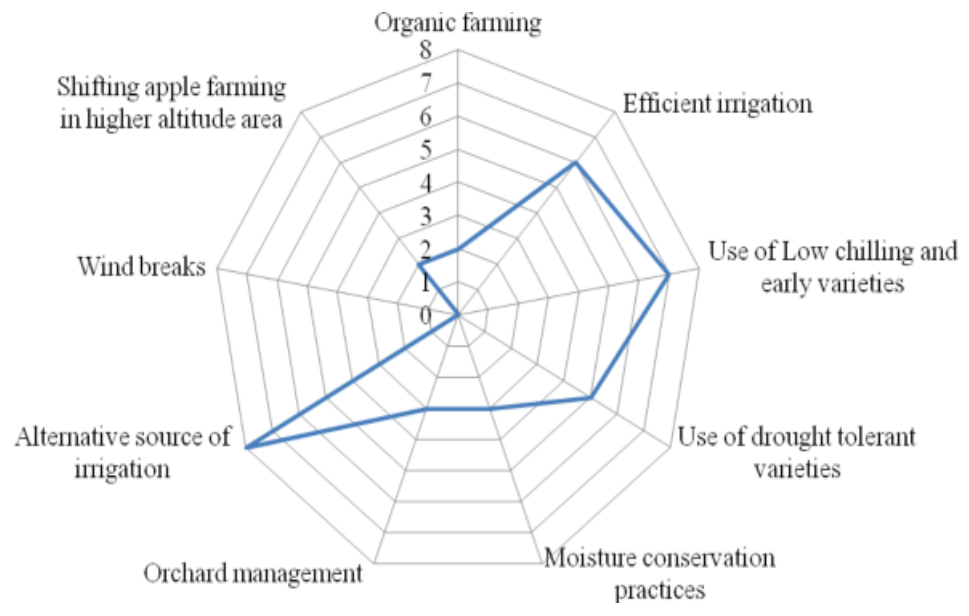

Figure 2. Potential adaptation strategies in the study site (Source: FGD, 2012)

\section{CONCLUSION}

Apple is a major fruit of the high hills of Nepal. The yield of apple is low due to various factors. Changing climate particularly increased temperature and resultant shortage of irrigation water seems a major factor among several factors that limits the production. The study indicated that increased temperature, drying up of existing water, frequent and increased Northern wind, high speed wind, less snowfall and long drought spells are the major climate hazards in Mustang district which are contributing to the decreased apple production. As measures, use of low chilling, early and drought tolerant varieties of apple; use of efficient irrigation methods and conservation agriculture practices are the adaptation practices that need to be promoted. Some initiatives have already been taken by local communities in this regards viz; uplifting irrigation water from Kaligandaki to irrigate apple orchard and organizing apple growers in group. The findings of this study may help the authorities in planning and designing climate resilient practices minimizing the negative impacts of climate change in apple production in Mustang and other apple producing districts. This will ultimately help to increase the apple production and productivity that will support the livelihoods of apple growers in Nepal. 


\section{REFERENCES}

Devkota, L.N. 1999. Decidious fruit production in Nepal. In: M.K. Papademetriou and M. Herath (eds), Decidious fruit production in Asia and the Pasific. Food and Agriculture Organization of the United Nations Regional Office for Asia and the Pacific Bangkok, Thailand. Available: http://www.fao.org/docrep/004/ab985e/ab985e09.htm\#bm9

Eriksson, M., Jianchu X., Shrestha A.B., Vaidya, R. A., Nepal S., Sandstrom, K. 2009. Changing Himalayas, impact of climate change on water resources and livelihoods in the greater Himalayas. ICIMOD, Kathmandu.

FNCCI. 2012. Balanced Economic Growth. One District one Product. Local Employment Income Generation and Food Security. Federation of Nepalese Chambers of Commerce and Industry/Agro Enterprise Center, Kathmandu, Nepal.

Hall, J. N, Moore S., Harper, S. B., Lynch, J. W. 2009. Global variability in fruit and vegetable consumption. Am J Prev Med. 2009;36(5):402-9. e5. Available at: http://www.ncbi.nlm.nih.gov/pubmed/19362694

IPCC. 2007. Climate Change Impacts, Adaptation, and Vulnerability: Contribution of Working Group II to the Fourth Assessment Report of the Intergovernmental Panel on Climate Change. Summary for Policy Makers.

IPCC. 2002. Climate change and biodiversity. Intergovernmental Panel on Climate Change. Technical Paper V. Geneva: IPCC.

Malla, G. 2008. Climate change and its impact on Nepalese Agriculture. The Journal of Agriculture and Environment, 9: 62-68.

MoAD. 2012. Statistical Information on Nepalese Agriculture. Government of Nepal, Ministry of AgriculturalDevelopment, Agri-Business Promotion and Statistics Division, Singha Durbar, Kathmandu Nepal.

MoAC. 2010. National Agriculture Sector Development Priority (NASDP) for the Medium-Term $(2010 / 11-2014 / 15)$. Ministry of Agriculture and Cooperatives, Government of Nepal. Kathmandu, Nepal.

Shrestha, A.B., Wake C.P., Mayewski P. A., Dibb J. E. 1999. Maximum temperature trends in the Himalaya and its vicinity: an analysis based on temperature records from Nepal for the period 1971-94. J. Clim. 12:2775-2786.

Annex 1. Farmers perception on climate change and apple production

\begin{tabular}{|c|c|c|c|c|}
\hline $\begin{array}{c}\text { Climatic } \\
\text { parameters }\end{array}$ & $\begin{array}{c}\text { Associated climate } \\
\text { hazards }\end{array}$ & $\begin{array}{l}\text { Farmers perceived } \\
\text { effects in apple } \\
\text { production }\end{array}$ & $\begin{array}{c}\text { Coping/adaptatio } \\
\mathrm{n} \text { actions acted } \\
\text { by farmers }\end{array}$ & Potential adaptation strategies \\
\hline Temperature & $\begin{array}{ll}\text { - } & \text { Increased } \\
\text { - } & \text { temperature } \\
\text { - } & \text { Long spell drought } \\
& \text { Water resources } \\
\text { drying up }\end{array}$ & 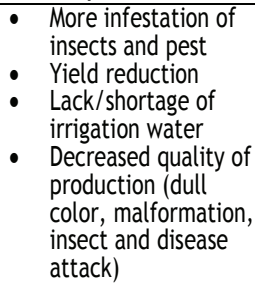 & $\begin{array}{l}\text { - } \text { Use of chemical } \\
\text { fertilizers } \\
\text { - } \quad \text { Irrigation canal } \\
\text { construction } \\
\text { - Plantation/afore } \\
\text { station } \\
\text { - Plantation, } \\
\text { gabion, check } \\
\text { dam, water } \\
\text { tank }\end{array}$ & $\begin{array}{l}\text { - Organic farming, use of bio } \\
\text { pesticides, use of well } \\
\text { decomposed manure. } \\
\text { - } \quad \text { Efficient irrigation methods } \\
\text { - Use of low chilling varieties, } \\
\text { early varieties etc. } \\
\text { - Use of drought tolerant } \\
\text { varieties } \\
\text { - Moisture conservation } \\
\text { practices like mulching, }\end{array}$ \\
\hline Precipitation & $\begin{array}{l}\text { - } \quad \text { Long spell drought } \\
\text { - } \quad \text { Dries up water } \\
\text { - } \text { sources } \\
\text { - } \quad \text { Llood and landslides } \\
\text { heavy rainfall } \\
\text { - } \quad \text { Less snowfall (change } \\
\text { in amount and timing } \\
\text { of snowfall) }\end{array}$ & $\begin{array}{l}\text { - Increase fruit drop } \\
\text { - Break down trees } \\
\text { and branches. } \\
\text { - Destruction of water } \\
\text { resources and } \\
\text { irrigation canal }\end{array}$ & - Nothing is done & $\begin{array}{l}\text { - Orchard management } \\
\text { (appropriate manure } \\
\text { application method, training } \\
\text { and pruning) } \\
\text { - Alternative source } \\
\text { of irrigation, i.e. } \\
\text { pumping water from } \\
\text { Kaligandaki river }\end{array}$ \\
\hline Wind & $\begin{array}{l}\text { - High speed wind } \\
\text { - } \quad \text { more northern wind }\end{array}$ & $\begin{array}{l}\text { - } \quad \text { Break down trees. } \\
\text { - } \quad \text { More infestation of } \\
\text { insects and pest } \\
\text { - Increase fruit drop }\end{array}$ & 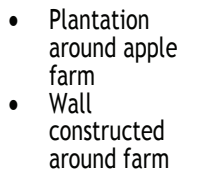 & - Good wind breaks \\
\hline
\end{tabular}

